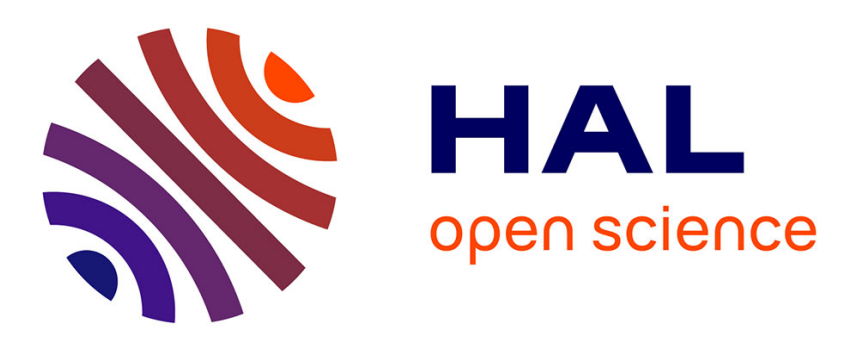

\title{
The French Case or the Hidden Dangers of a Long-Term State of Emergency
}

\author{
Cécile Guérin-Bargues
}

\section{To cite this version:}

Cécile Guérin-Bargues. The French Case or the Hidden Dangers of a Long-Term State of Emergency. The rule of crisis : terrorism, emergency legislation and the rule of law, Springer, 2018, 9783319744728. hal-01919684

\section{HAL Id: hal-01919684 \\ https://hal.parisnanterre.fr/hal-01919684}

Submitted on 12 Nov 2018

HAL is a multi-disciplinary open access archive for the deposit and dissemination of scientific research documents, whether they are published or not. The documents may come from teaching and research institutions in France or abroad, or from public or private research centers.
L'archive ouverte pluridisciplinaire HAL, est destinée au dépôt et à la diffusion de documents scientifiques de niveau recherche, publiés ou non, émanant des établissements d'enseignement et de recherche français ou étrangers, des laboratoires publics ou privés. 


\title{
The French Case or the Hidden Dangers of a Long-Term State of Emergency
}

\author{
Cécile Guérin-Bargues
}

\begin{abstract}
Since January 2015, French politics are regularly shaped by the scourge of terrorist operations carried out on its territory. State of emergency was declared in November 2015 and had several time been renewed since that time. Its legal regime has been modified and strengthened in both November 2015 and July 2016. The aim of this article is twofold. First, it underscores the tremendous extent of the executive power under state of emergency. Second, it aims at showing how state of emergency leads to paradigm shifts that affect the functioning of the French political powers. This change is not limited to security prevailing over liberty, but it is also apparent in many other fields. For instance, politicians tend to view state of emergency as the means needed to fight against a recurring terrorist danger. State of emergency that has been conceived as a legal answer to a temporary threat tends in France to become permanent. Its very nature is thus modified. Another paradigm shift can be seen in the fate of the balance of power doctrine. The classical doctrine according to which Parliament is expected to defend liberty and to impose limits on executive power tends to be forgotten. Not only every steps have been taken in order to avoid primary judicial review of the 20 November 2015 law. But Parliamentary debates also illustrate how much members of Parliament, under the pressure of a traumatised public opinion, are ready to give the executive power even more prerogatives than what is asked for. State of emergency thus appears as a perilous status: not only for everyday liberties but also because of a hidden danger: it may alter in the long run the normal functioning of public institutions.
\end{abstract}

\footnotetext{
C. Guérin-Bargues $(\bowtie)$

Institut Michel Villey pour la culture juridique et la philosophie du droit, University Paris Nanterre, Paris, France

e-mail: cecbargues@aol.com
} 


\section{Introduction}

The state of emergency has been at the heart of French political and legal life ever since its declaration on the night of 14 November 2015, following the attacks on the Bataclan concert hall. The institution was established ex nihilo by the law of 3 April 1955. At the time, it was intended to provide a means of dealing with the attacks by Algerian rebels on a territory that still belonged to France. Over the years, and with use, its legal status has undergone various changes. The most extensive such change resulted from the law of 20 November 2015 which extended the state of emergency declared on 14 November by three months and, under the guise of modernisation, further increased the powers of the administration. It has since been extended on four further occasions. ${ }^{1}$

The scope of the powers conferred upon the administration (the Prime Minister, the Minister of the Interior and Prefects ${ }^{2}$ ) has varied from one extension to the next. For instance, the possibility of conducting house searches by day as well as by night, which is one of the measures that infringe most heavily upon constitutional liberties, was authorised from 14 November to 26 May 2016. The law of 20 May 2016 extended the state of emergency once again. However, by making no mention of such searches, it put an end to them. ${ }^{3}$ This possibility was nonetheless reactivated and extended by the law of 21 July 2016, following the attack in Nice and was maintained by the law of 19 December 2016.

The other powers conferred upon the administration, however, derive simply from the implementation of the state of emergency itself and thus do not require any specific mention in the prorogation bill. These powers are nonetheless extended to a remarkable degree, with the possibility of: placing anyone suspected of posing a threat to security and public order under house arrest, in a place determined by the prefect ${ }^{4}$; regulating the right to stay and freedom of movement of people and vehicles $^{5}$; and disbanding associations that could compromise public order. ${ }^{6}$ The administration also has the power to: 'order the temporary closure of entertainment

\footnotetext{
${ }^{1}$ In addition to Law No. 2015-1501 of 20 November 2015, which extends the state of emergency by three months, mention should also be made here of Law No. 2016-162 dated 19 February 2016 (for another three-month extension); Law No. 2016-629 of 20 May 2016 (two-month extension); Law No. 2016-987 dated 21 July 2016 (six-month extension) and Law No. 2016-1767 dated 19 December 2016 (seven-month extension).

${ }^{2}$ Prefects are representing the Minister of the Interior within the French territory.

${ }^{3}$ Specific mention should in fact be made of Article 11, subparagraph 1, of the law of 3 April 1955, in the decree declaring the state of emergency, or in the law that extends its enforcement, to authorise the carrying out of searches by day as well as by night.

${ }^{4}$ Law of 3 April 1955, Article 6.

${ }^{5}$ Article 5.

${ }^{6}$ Article 6-1.
} 
venues, drinking establishments and meeting places"7; forbid processions and shows ${ }^{8}$; search bags and vehicles ${ }^{9}$; and order the handing over of weapons. ${ }^{10}$ Since the Algerian War (1954-1962), never has such a broadly conceived emergency regime been applied in metropolitan France, and over such an extended period of time. If the state of emergency remains in force until the date specified by the law of 19 December 2016, France will have been under this regime, which infringes upon public liberties to a particularly marked degree, for over twenty months, from 14 November 2015 to 15 July 2017.

The efficacy and legitimacy of such a long-term application of this legal system are certainly questionable.

Its efficacy in practical terms is difficult to measure. A parliamentary report has in fact examined around ten attacks that were thwarted thanks to the actions of the intelligence and security services. ${ }^{11}$ Nonetheless, it is impossible to ascertain the specific role played by the state of emergency provisions in this regard, as compared to the rules of ordinary law. ${ }^{12}$ Any such role was no doubt minor; the report notes that specialists in the fight against terrorism, despite having been interviewed during the state of emergency, make barely any mention of the measures taken within its framework. ${ }^{13}$ In fact, the efficacy of the state of emergency appears to rapidly decrease the further one gets from the date on which it was declared. As such, a statement issued on 13 January 2016 by the Committee of the National Assembly, which is responsible for overseeing the state of emergency, indicates that, by that point in time, the mechanism had already exhausted most of its effects. The figures relating to the two most widely employed measures speak for themselves. On 12 January 2016, 3021 police searches and 381 administrative summonses had already been issued. As the public authorities wanted to benefit from the element of surprise associated with the declaration of a state of emergency, almost a third of these searches were ordered during the seven days following the Bataclan attacks. ${ }^{14}$ The efficacy of the mechanism, which derives from its

\footnotetext{
${ }^{7}$ Article 8 .

${ }^{8}$ Article 8.

${ }^{9}$ Article 8-1.

${ }^{10}$ Article 9.

${ }^{11}$ National Assembly, Pietrasanta Report, drawn up on behalf of the commission of enquiry on the steps taken by the State in the fight against terrorism, 5 July 2016, 262.

${ }^{12}$ One of the projects, at least, was thwarted following an administrative search carried out under the state of emergency. Ibid. p. 143.

${ }^{13}$ Ibid. p. 262.

${ }^{14}$ The updated figures, as at 11 July 2016, confirm such a concentration of measures in the first weeks of the state of emergency, when there were no fewer than 3594 searches, and 400 summonses.
} 
destabilising effect, is thus closely linked to the element of surprise, which is quick to dissipate. ${ }^{15}$ In short, as one senator stressed during the debate on 20 July 2016 on the extension of the state of emergency: 'renewing [...] the state of emergency will have very little practical effect'. ${ }^{16}$

Moreover, recourse to the state of emergency, as an emergency form of legislation, seems in some senses superfluous, given that identical measures can be adopted under ordinary legislation. This is the case, for instance, with the procedure for blocking access to sites that incite terrorism. Pursuant to Article 11 of the Law of 1955, as amended, this procedure merely 'duplicates' an identical legislative framework introduced in $2014 .{ }^{17}$ Furthermore, several ordinary laws were adopted in the last few months to reinforce the fight against organised crime, terrorism and their financing. ${ }^{18}$

The specific contribution of the state of emergency to the fight against terrorism is thus minimal. When an offence is discovered, administrative searches can nonetheless result in criminal proceedings. In December 2016, out of a total of over 4000 administrative searches, almost 670 led to such proceedings. However, only a few of these were linked to terrorism, with the vast majority concerning incitement to terrorism. ${ }^{19}$ Ultimately, only twenty proceedings that resulted, at least in part, from an administrative search actually led to the anti-terrorist section of the Paris Public Prosecutor being called upon. ${ }^{20}$

Such an observation naturally leads one to call into question the link between such measures and the terrorist threat, which was used to justify the implementation of the state of emergency and its extensions. State of emergency legislation should not be placed on the same level as ordinary legislation. Like any exceptional regime, its use should be limited to the strictly necessary. This is evidently not the case, though, since this emergency legislation, the implementation of which was justified on the basis of exceptional circumstances, is essentially being used in the manner of ordinary law. Such a process ultimately results in the transformation of a legal system that is reactive in nature (the state of emergency as a reaction to an attack) into a preventive mechanism. Yet, conferring a preventive function upon emergency legislation implies that it is regarded, at all times, as a possible

\footnotetext{
${ }^{15}$ In this context, the Pietrasanta Report mentions a noteworthy anecdote recounted by Mr. Partick Mairesse, Director of Public Safety for the Department of Isère: 'As soon as the second day after the declaration of the state of emergency, we were greeted with the outburst: 'At last! I'd been waiting'. For some, this is a question of standing! What's more, we found a computer at the home of a radicalised individual with its contents entirely wiped, except for one result in the search history relating to the state of emergency! And that was only Sunday evening'! ibid. p. 262.

${ }^{16}$ Jacques Mézard, Official Journal, debates 20 July 2016.

${ }^{17}$ Article 12 of Law No. 2014-1353 dated 13 November 2014, which strengthened the provisions concerning the fight against terrorism and amended the law of 21 June 2014 to support confidence in the digital economy.

${ }^{18} \mathrm{See}$, for instance, the French Criminal Code, Articles 421-2-1, -2, -3, -4, -5, etc.

${ }^{19}$ Discovery of video messages or flags, for example.

${ }^{20}$ Pietrasanta Report, as above, p. 262.
} 
alternative to the well-calibrated procedures and measured solutions that make up the legal system in times of peace.

The state of emergency thus appears to have only a very relative effect in the fight against terrorism. However, as soon as it is necessary to call into question the foundations of the normal operations of French public institutions, it becomes remarkably effective. Article 16 of the Declaration of the Rights of Man and of the Citizen, which forms part of the constitutional norms in force in France, specifies that: "Any society in which rights are not guaranteed, or in which there is no determined separation of powers, has no Constitution'. One could nonetheless justifiably worry that the perpetuation of a state of emergency in France might result in the calling into question of both (I) the balance of powers and (II) the guarantee of rights.

\section{Calling into Question the Balance of Power}

The state of emergency disrupts the separation of power by emphasising the primacy of the executive branch (2.1) with the support of legislative powers (2.2) and without any prior control by the Constitutional Council (2.3).

\subsection{The Primacy of the Executive}

The appropriation of power by the executive in connection with the state of emergency is by no means a new development. Indeed, a dual appropriation, of both a formal and material nature, can be seen as early as 1960. It was through an Order issued on 25 April $1960^{21}$ that the Parliament conferred the power to declare a state of emergency upon the President of the Republic. However, this administrative act, which amended the law of 3 April 1955 on an essential point, was passed through a parliamentary enabling act. ${ }^{22}$ This act authorised the government at the time to undertake a certain number of legislative measures, 'under the signature of General de Gaulle', President of the Republic at the time. The Head of State thus assigned himself the authority to declare a state of emergency. Since then, in accordance with the primacy of the executive under the Fifth Republic,

\footnotetext{
${ }^{21}$ Order No. 60-372 of 15 April 1960, which amends certain provisions of Law No. 55-385 of 3 April 1955, establishing a state of emergency.

${ }^{22}$ Law No. 60-101 of 4 February 1960, which, under Article 38 of the Constitution, authorises the government to take certain measures in order to maintain law and order, safeguard the State and improve peace-making and administration in Algeria. This mechanism is provided for under Article 38 of the Constitution. Pursuant to Article 13 of the Constitution, the President of the Republic is responsible for signing orders and decrees deliberated upon in the Council of Ministers.
} 
'a state of emergency is declared by a decree from the Council of Ministers', 23 that is, through a text signed by the Head of State. As such, the President of the Republic enjoys extended discretionary power when it comes to declaring a state of emergency and establishing its scope of application at the territorial level. Indeed, this dimension was very clearly conveyed during the televised appearance of the President of the Republic, François Hollande, on the evening of 13 November 2015, while the attacks in Paris were still underway. Before the Council of Ministers had even had time to meet, he specified that 'they would make two decisions': in addition to calling for the 'closure of the borders', 'a state of emergency would be declared [...] across the territory'.

The power to declare a state of emergency is a highly important presidential prerogative. Followed by implementing decrees, it immediately leads to a considerable strengthening of the powers conferred upon the administrative police authorities, as has already been suggested. However, in practice, the implementation of a state of emergency illustrates that these prerogatives are often quickly employed for reasons other than those initially used to justify the declaration of the state of emergency. For example, not long after the attacks on November 2015, Paris was set to host COP 21, the United Nations conference on climate change. Twenty-seven house arrests and 130 measures prohibiting demonstrations were ordered against environmental campaigners who clearly had no links with Salafist elements. These house arrests testify to the freedom of interpretation that the state of emergency grants the executive branch since it assumes the right to act for reasons beyond those that served to validate the declaration of the state of emergency in the first place. It is true that, after twelve days, the state of emergency can only be extended by law. The significance of such an intervention by the Parliament cannot, however, be overestimated, where circumstances favour a consensus between the executive and legislative branches and the freedom of the former to act.

\subsection{Parliamentary One-Upmanship}

First of all, we will examine the procedure for the adoption of the law of 20 November 2015. This law not only extended the state of emergency by three months but also substantially amended the law of 3 April 1955. Despite this dual effect, however, it was adopted extremely quickly thanks to a particularly strong consensus between the two chambers: it was passed less than a week after the state of emergency was declared. Clearly, the priority for parliamentarians was to provide the government with the means to protect public order, rather than to set themselves up as guardians of liberties.

The classic doctrine, according to which the purpose of legislative power is to restrict the repressive inclination of the executive branch, appears to lose most of its

\footnotetext{
${ }^{23}$ Order No. 60-372 dated 15 April 1960, as mentioned above, Art. 2. Para. 1.
} 
force during a state of emergency. Far from acting as an opposing power, Parliament allowed itself to be swayed by majority logic and, faced with traumatised public opinion, did not hesitate to overstep the government's wishes. For example, it was on the basis of a proposal made by parliament that house arrests for individuals were extended to twelve hours, ${ }^{24}$ rather than eight as proposed in the draft law. Furthermore, certain parliamentarians took very little heed of constitutional constraints by proposing round-the-clock standby duty at home, for instance, at the risk of transforming house arrests into an administrative detention which, under Article 66 of the French Constitution, requires the intervention of a judicial judge. $^{25}$ Equally, the new Article 11(2) of the amended Law of 1955, concerning online services, the redundancy of which has already been stressed, also resulted from a parliamentary initiative. ${ }^{26}$ It was originally intended to limit the procedural safeguards established by the law of 2014. Numerous other examples could be proposed. Suffice it to say that, as a rule, amendments proposed by parliamentarians that were geared at achieving that difficult balance between the need for effectiveness and respect for laws and liberties were almost systematically rejected. The options retained offered the advantage of allowing for 'greater policy manoeuvreability'. ${ }^{27}$

The parliamentary debates that presided over the adoption of the fourth extension of the state of emergency, by the law of 21 July 2016 (following the attack in Nice on the evening of 14 July), generated much more heated exchanges than the previous ones. These were nonetheless brief; once again, the law was adopted in under $48 \mathrm{~h}$ even though the public authorities had declared, up to the morning of 14 July, that it would be possible to put an end to the state of emergency and that ordinary legislation would from then on suffice in the fight against terrorism. The debates thus testified to a clear calling into question of the government's capacity to guarantee the safety of the French people. This parliamentary one-upmanship affected, first of all, the length of the extension; the extension was for six months, even though the government had proposed that it be for three. The parliamentary amendments also led to a further strengthening of the provisions of the law of 3 April 1955. The Senate adopted a particularly ambiguous provision, facilitating the closure of places of worship that are the site of statements inciting hatred and

\footnotetext{
${ }^{24}$ Amendment 40, defended by Mr Ciotti during the debate in the National Assembly on 19 November 2015.

${ }^{25}$ Amendment No. 4 by Mr. Larrivé in the Commission. In its decision QPC 2015-527, dated 22 December 2015, the Constitutional Council stressed that house arrests cannot last longer than twelve hours. However, this did not stop certain senators, during the debates on the extension of 21 July, following the attacks in Nice, from proposing an amendment to increase the duration of house arrests that can be ordered by the Minister of the Interior from twelve hours to twenty-four hours. Rachline Amendment, senatorial debates of 20 July 2016.

${ }^{26}$ Initiative of the radical group in the National Assembly.

${ }^{27}$ This expression is taken from an address by the Madame Secretary, during a debate in the Commission concerning the laws of the National Assembly, which took place on 19 November 2015.
} 
violence. ${ }^{28}$ In fact, one need only recall one of the hypotheses put forward by the law of 20 November 2015. This 'media-oriented' amendment thus led to 'the addition of texts rather than the application of existing ones'. ${ }^{29}$ The law of 21 July also authorised a wide-scale prohibition of gatherings and marches, not for the classic reasons associated with public order, but simply in light of the administrative authorities' incapacity to guarantee participants' safety. ${ }^{30}$ Another amendment led to the introduction of a system of preventive identity checks, including baggage and vehicle searches, without the authorisation of the public prosecutor, contrary to the stipulations of ordinary law. ${ }^{31}$ Lastly, the law circumvents the effects of the Constitutional Council's decision of 19 February 2016, which judged the seizing of material and computer data during administrative searches to be unconstitutional due to the lack of authorisation by a judge. The solution adopted is unconvincing given the requirements of the Constitutional Council. For, pursuant to Article 5 of the law of 21 July 2016, seizures can be conducted freely, and only the utilisation of data requires the authorisation of an administrative judge hearing applications for interim measures.

However, strengthening the more freedom-curbing provisions of the law of 3 April 1955-with the agreement, or even on the initiative of, parliamentarians - is not the only effect that the laws of 20 November 2015, 19 February 2016, 20 May 2016, 21 July 2016 and 19 December 2016 have in common. For in addition, neither one is subject to any form of a priori control by the Constitutional Council.

\subsection{The Absence of Any a Priori Referral to the Constitutional Council}

Two types of constitutionality controls exist in France. A priori controls are carried out prior to the enactment of a law. This process is not obligatory and involves a referral to the Council, either by a political authority (the President of the Republic, the Prime Minister, the President of the National Assembly or of the Senate) or by a minority of parliamentarians (at least 60 deputies or 60 senators). It applies to all constitutional norms, whether substantive (rights and freedoms) or procedural in nature. A posteriori control was introduced more recently. Since 1 March 2010, this procedure has enabled the Constitutional Council to control legislative provisions already in effect. It is applied in the case of pending lawsuits and exclusively in relation to the rights and freedoms guaranteed by the Constitution. It presupposes

\footnotetext{
${ }^{28}$ Article 3 of the law of 21 July 2016, amending Article 8 of the law of 3 April 1955.

${ }^{29}$ These were the words of Senator Jacques Mézard, on 20 July 2016, during the examination by the Commission of the future law of 21 July 2016.

${ }^{30}$ Idem.

${ }^{31}$ Article 4 of the law of 21 July 2016, which inserted Article 8-1 into the law of 3 April 1955. This was authorised by the prefect; the prosecutor merely needed to be informed.
} 
that a litigious provision has not been subject to any a priori control, except in the event of a change in circumstances, in law or in fact.

Every effort appears to have been made, and each time state of emergency has been renewed and strengthened by law to avoid an a priori referral to the Constitutional Council. Yet a priori referral could have made it possible to render a posteriori control inadmissible. During the parliamentary debates in November 2015, however, the Prime Minister repeatedly declared that he was 'extremely hesitant about a referral to the Constitutional Council', inasmuch as 'it is always risky to call upon the Constitutional Council'. ${ }^{32}$ This public admission, on the part of a Prime Minister, of personal distrust in an institution intended to offset majority rule is clearly shocking. Above all, it is a glaring contradiction of an address apparently geared at bringing the state of emergency under the rule of law. How can the executive branch so implicitly proclaim its desire to have free rein, while at the same time referring to the notion of the rule of law, which necessarily implies subjecting executive power to a system of surveillance and increased monitoring ${ }^{33}$

The fact remains, however, that no referral to the Constitutional Council was made before the promulgation either of those laws. Yet a posteriori control of constitutionality can only partially compensate for the absence of a priori control. Thus, the bill of extension of 21 July 2016 includes several provisions that relate not to the extension of the state of emergency, but to the escalation of the fight against terrorism. ${ }^{34}$ These form Title II, which underscores the heterogeneous nature of the law and testifies to the incorporation of the state of emergency in the fight against terrorism. Essentially, this is a series of measures added by the more radical parliamentarians, and which had hitherto been rejected by the government. These concern: the withdrawal of automatic reduced sentences and of the possibility of placing people convicted of terrorist offences under a restricted-release regime $^{35}$; harsher sentences ${ }^{36}$; and the adoption of a mandatory ban on entering the French territory. ${ }^{37}$ These provisions do not amend the law of 3 April 1955, then, which is the legislative basis of the state of emergency, but rather the Penal Code and the Code of Criminal Procedure. Yet Article 45 of the French Constitution prohibits 'rider legislations', that is, provisions introduced by an amendment that bears little connection with the original text. ${ }^{38}$ However, this calling into question of an enacted law constitutes a violation of constitutional rights and freedoms,

\footnotetext{
${ }^{32}$ Senate, session on 20 November 2015.

${ }^{33}$ On this subject, see Rosanvallon (2015).

${ }^{34} \mathrm{Cf}$. Circular dated 22 July 2015 concerning the state of emergency. Presentation of the provisions of Law No. 2016-987 dated 21 July 2016 to extend the application of Law No. 55-385 dated 3 April 1955 regarding the state of emergency and introduce measures to step up the fight against terrorism. Bulletin officiel du Ministère de la Justice (Official Bulletin of the Ministry of Justice), JUSD1620976C.

${ }^{35}$ Article 8 of the law of 21 July 2016.

${ }^{36}$ Article 13.

${ }^{37}$ Article 14.

${ }^{38}$ Avril (2014), 240.
} 
rather than simply failing to comply with parliamentary procedure. As such, these provisions could have been censured by the Constitutional Council, as part of an a priori control process, but not within the framework of a posterior control. ${ }^{39}$

The long-term state of emergency, the efficacy and legitimacy of which is indeed questionable, thus appears to be fraught with risks. Not only does it increase the prerogatives of the administrative powers; it also encourages the public authorities to emancipate themselves from the balance of power, involving the prevalence of the executive branch, which is quick to misuse the powers conferred upon it; a parliamentary one-upmanship geared at overstepping the prerogatives required by the government to maintain public order; and abandoning the task of protecting rights and freedoms to those due to be tried, through a referral to the Constitutional Council under a system of a posteriori control. The classic republican doctrine, which established Parliament as the main guarantor of freedoms, now seems a thing of the past. Yet if the balance of power is called into question, the same can also be said for guaranteed rights.

\section{The Lack of Guaranteed Rights}

The laws of 20 November 2015 and 21 July 2016 strengthen the powers of the administration, without any real prior judicial control. Despite being intended to act as a guarantor of freedoms, the ordinary judge is removed from the control process for all measures adopted under a state of emergency, in favour of the administrative judge (3.1). As far as the legal basis for this state of exception is concerned, it is in fact subject only to a posteriori control, which has only marginally improved upon the safeguarding of liberties (3.2).

\subsection{Removal of the Ordinary Judge in Favour of the Administrative Judge}

Since November 2015, the French Government has continually stressed that the state of emergency was being strengthened to better defend the rule of law. To avoid contradiction, it therefore had no choice but to provide safeguards. However, in France, the actions of the administration are traditionally brought before a specific judge and subject to a specific law. This explains the provision of the law of 20 November 2015, which adds Article 14(1) to the law of 3 April 1955. Pursuant to this article, 'measures taken on the basis of this law are subject to the control of the administrative judge'. Although the administrative judge has indeed often strived to safeguard freedoms, the provision does not in fact add anything to

\footnotetext{
${ }^{39}$ On this subject, see Cassia (2016a), 148.
} 
ordinary law. In French law, as a matter of principle, administrative acts fall under the control of the administrative judge.

Acts adopted under a state of emergency are thus subject to the control of the administrative judge. However, Article 66 of the Constitution establishes the judicial authorities, rather than the administrative judge, as the guarantor of individual freedom. The role of the ordinary judge is nonetheless restricted here to the dimension established by the combined effect of state of emergency legislation and the jurisprudence of the Constitutional Council. ${ }^{40}$ This is set forth principally in Article 11 of the law of 3 April 1955, as amended by the laws of 20 November 2015 and 21 July 2016. This article stipulates that the public prosecutor must be notified without delay, by being provided with a report on the search and the referral procedure.

However, the mechanism actually restricts rather than protects freedoms. ${ }^{41}$ Having been duly informed of the procedure, without delay, the judicial authority can neither request further information, nor interrupt the process. This allows a judicial investigation to be launched immediately if evidence to suggest an offence has been committed is discovered. Only in such a case can a judge be called upon, pursuant to Article III-5 of the Penal Code, to assess the legality of the acts of the administration. For example, a criminal court can examine whether a search complies with the provisions of the Emergency Act if the related proceedings are based on evidence obtained during the search. However, one cannot overemphasise the frequency with which such an assessment of administrative acts is conducted by the judicial authorities. Administrative searches followed by judicial investigations are in fact rare. According to the figures released by the Ministry of the Interior in June 2016 , only $6 \%$ of administrative searches resulted in a criminal prosecution. ${ }^{42}$

Thus, as a rule, under the current system, the implementation of a state of emergency is subject only to the control of administrative judges. What are the concrete effects of this?

French administrative law allows for several types of proceedings, drawing a schematic distinction between interlocutory and substantive proceedings. Interlocutory proceedings offer anyone due to be tried the possibility of obtaining an interim decision, on very short notice, to protect themselves against an unlawful administrative decision. To increase the efficacy and promptness of this type of plea, the admissibility criteria for requests and the procedural requirements are less stringent. ${ }^{43}$ With respect to the state of emergency, interlocutory orders are generally requested by a claimant who believes there to be an urgent need to stay an administrative decision affecting their rights and freedoms, without awaiting a judgement on the merits of the case.

\footnotetext{
${ }^{40} \mathrm{Cf}$. infra.

${ }^{41}$ Here, we are reiterating part of N. Roret's analysis (Roret 2016, 13).

${ }^{42}$ Cassia (2016b).

${ }^{43}$ The administrative law concerning emergency procedures was significantly modernised and improved upon by the law of 30 June 2000 .
} 
With regard to the large number of individual decisions based on laws relating to the state of emergency, there are still very few administrative proceedings and they mainly concern house arrests. On the basis of a rigorous analysis of the statistics provided by the Council of State on 25 February 2016, Paul Cassia proposes that the proportion of challenged resolutions, in 400 or so house arrests, was scarcely higher than $18 \% .^{44}$ Of these, only 11 house arrests were suspended, giving a success rate of less than $3 \%$. Moreover, the rate of administrative proceedings seems to decrease the longer the state of emergency lasts. ${ }^{45}$ To explain these figures, the authors mentions several factors: a lack of knowledge of the possible appeals procedures by the parties concerned; a lack of confidence in administrative jurisdiction; or simply the constraints linked to the limitation of movement associated with house arrests. ${ }^{46}$

Administrative searches, which are by far the most widely used measures, are thus one of the measures that form a blind spot in the control process. By their very nature, they are unlikely to be obstructed, even by means of an interlocutory proceeding. And, in a best-case scenario, they can be subject only to a liability action against the State, to obtain financial compensation. The intervention of an administrative judge is thus of limited use since it occurs a posteriori, after the violation of rights and freedoms. The 3594 house searches conducted between 14 November 2015 and 25 May 2016 only gave rise to a very limited number of litigations: just 22 pleas, concerning compensation litigations. ${ }^{47}$ Yet administrative house searches can infringe upon a considerable number of fundamental rights, from the individual's right to privacy, to the law of presumed innocence, the right to lead a normal family life and the right to the protection of personal data. ${ }^{48}$ That is, if the control of the administrative judge does not provide a sufficient guarantee. What guarantee, then, is offered by the constitutional judicial authority acting on an a posteriori basis?

\subsection{The Failure of a Posteriori Controls}

As there was no a priori referral to the Constitutional Council on the matter of the amendments to the law of 3 April 1955, reference must be made to the a posteriori control decisions made since the promulgation of the law of 20 November 2015. An analysis of such decisions, however, merely supports the impression that this state of emergency is only subject to a low level of control.

\footnotetext{
${ }^{44}$ Cassia, Contre l'état d'urgence (n 43) 156.

$45_{\text {ibid }} 157$.

46 ibid.

${ }^{47}$ Figures taken from the summary table, updated as at 11 July 2016 and drawn up by the National Assembly using data provided by the Ministry of the Interior.

${ }^{48}$ See, for example, Cassia (2015).
} 
The first a posteriori control occurred in 22 December 2015. It followed a plea made by an environmentalist known for his radical activism against the house arrest he was placed under during the 15 days of COP $21 .{ }^{49} \mathrm{He}$ criticised Article 6 of the law of 3 April 1955, as amended by the law of 20 November 2015, for failing to observe the rights guaranteed under Article 66 of the Constitution, and for unjustifiably infringing upon freedom from restraint. Article 6 authorises the Minister of the Interior to 'place under house arrest $[\ldots]$ any person $[\ldots]$ in respect of whom there are serious grounds for believing that their behaviour is a threat to public order and safety'. Article 66 of the Constitution establishes the judiciary as the guarantor of freedom.

The question asked to the Constitutional Council was smart inasmuch as it does not contest the terms of Article 6 so much as its application in the present case, that is, the lack of any link between the reasons for the declaration of a state of emergency, on the one hand, and for a house arrest on the other. ${ }^{50}$ Yet the Council was content to rely once again upon the above-mentioned formulation from Article 6 , making no reference to the reasons for the declaration of the state of emergency. By dint of such an omission, it approves of the administrative authorities using their powers in a manner that bears no relation to the reasons for which the state of emergency was declared in the first place.

Moreover, the regime of house arrest is found to conform with constitutional freedoms and rights. In fact, the Council underscores the administrative nature of a house arrest ruling. It is found to be sufficiently well-defined and limited as to not constitute a deprivation of individual liberty which, pursuant to Article 66 of the Constitution, could fall within the jurisdiction of an ordinary judge. ${ }^{51}$ In concrete terms, such a decision means that the administration is not subject to any control by a judge, on a matter that is nonetheless highly sensitive. Little attention is paid, therefore, to 'the constituent's desire to establish the judicial authorities, including (and perhaps above all) in times of crisis, as the guarantor of individual liberty'. ${ }^{52}$

The argument relating to freedom from restraint was also rejected. The Constitutional Council refused to see administrative house arrest as 'a disproportionate violation of' this liberty, to the advantage of two considerations. The first is both legal and contextual: a house arrest can only be delivered once a state of emergency has been declared and comes to an end when the latter expires. ${ }^{53}$ The second is more 'respectful of liberties': house arrests are subject to the control of an administrative judge, who is responsible for ensuring that this measure is necessary, appropriate and proportional to its intended purpose ${ }^{54}$ However, the Constitutional Council in no way inhibits the logic behind the state of emergency, which greatly

\footnotetext{
${ }^{49}$ On this decision, see Roblot-Troizier (2016).

${ }^{50} \mathrm{See}$, for example ibid.

${ }^{51}$ Recital 5, in fine.

${ }^{52}$ Baranger (2016a).

${ }^{53}$ Recitals 11 and 13 .

${ }^{54}$ Recital 12.
} 
increases the room for manoeuver of the administration, which falls under the sole control of its judge - the administrative judge. ${ }^{55}$

The two a posteriori decisions made on 19 February 2016 follow the same rather unprotective pattern.

In the first of these decisions, Article 8 of the law of 1955, which allows for the prohibition of meetings and the administrative closure of certain places, is found to be in conformity with the Constitution. In response to the League of Human Rights, which denounced the lack of framework for the prerogatives conferred upon the administration, the Constitutional Council again stressed the temporary and conditioned nature of the state of emergency, ${ }^{56}$ and the guarantee provided by the control of proportionality conducted by the administrative judge. ${ }^{57}$

The second a posteriori control, dated 19 February 2016, which relates to Article 11 of the law of 1955, as amended by the law of 20 November 2015, concerning administrative searches, ${ }^{58}$ is slightly more protective. On the one hand, the Constitutional Council limited the possibility of carrying out searches at night, ruling that they must be justified 'by a situation of emergency or by the impossibility of carrying them out during the day'. ${ }^{59}$ On the other hand, it declared the provision of Article 11, which authorises the forces of order to 'copy all computer data to which access could have been gained during the search' ${ }^{, 60}$ to be unconstitutional. This measure is in fact 'comparable to a seizure', and, as such, should be subject to prior authorisation by a judge.

This relative liberalism on the part of the Constitutional Council did not last long, however. Indeed, when questioned, at the time, about the constitutionality of Article 11 (subparagraph 1, concerning searches) of the law of 3 April 1955, prior to its amendment by the law of 20 November $2015,{ }^{61}$ the Constitutional Council, by the a posteriori control decision of 23 September 2016, judged this provision to be unconstitutional. It found that 'by failing to subject the use of searches to any conditions and to provide any guarantee in relation to their implementation', the legislator had not ensured 'a balance between the constitutional goal of safeguarding public order and the individual's right to privacy' ${ }^{62}$ Nonetheless, the Council immediately limited the scope of its decision through the power conferred upon it by Article 62, subparagraph 2, of the Constitution. To prevent the declaration of unconstitutionality of legislative provisions already in application from

\footnotetext{
${ }^{55}$ On this point, see Le Bot (2016).

${ }^{56}$ Recitals 7 and 9.

${ }^{57}$ Recital 8.

${ }^{58}$ Decision 2016-536 QPC dated 19 February 2016.

${ }^{59}$ Recital 10.

${ }^{60}$ Recital 14.

${ }^{61}$ This concerns the first paragraph of Article 11 which, in the version prior to the law of 20 November 2015, stated that a law or decree to declare a state of emergency, or a law to extend it 'can, by way of an express provision: (1) confer upon the administrative authorities referred to in Article 8 the power to order house searches by day and by night'.

${ }^{62}$ Decision no. 2016-567/568 QPC dated 23 September 2016, Recital 8.
} 
generating too much legal uncertainty, it maintains the power to 'determine the conditions and limits under which the effects brought about by the provision can be questioned'. Here, the Council did not hesitate to render its ruling of unconstitutionality ineffective by specifying, at the end of the decision that 'measures taken on the basis of provisions declared to be unconstitutional cannot be disputed on the basis of such unconstitutionality in any consecutive criminal proceedings'.

The analysis of the recent decision of 2 December $2016^{63}$ also supports the impression that state of emergency is only subject to a low level of control. The plea relates to the solution set out by the legislator to get around the above-mentioned decision made on 19 February 2016. In this decision, the Constitutional Council declared the provision of Article 11, which authorises the forces of order to 'copy all computer data to which access could have been gained during the search' to be unconstitutional for want of prior authorisation by a judge. In reaction, the legislator limited the authorisation required by a referral administrative judge to the exploitation of data only but not to its mere copy. This minimal legislative guarantee was considered sufficient by the Constitutional Council.

In the light of its characteristic weakness, this a priori control could be said to correspond to the character of the state of emergency control process as a whole. However, the weakness of this control system should almost certainly be associated with the nature of the state of emergency itself, as conceived under French law. By authorising the administration to adopt security measures that heavily infringe upon freedoms and rights, it inevitably 'blurs, to a certain extent, the separation between the political, administrative and judicial authorities'. ${ }^{64}$ In so doing, it necessarily weakens any attempt to control, or rather, to limit. Such an inflexion of the normal functioning of public institutions could arguably be seen as the primary risk of its perpetuation.

\section{References}

Avril P, Gicquel JE, Gicquel E (2014) Droit Parlementaire, 5th edn. LGDJ

Baranger D (2016a) Quel «État de Droit»? Quels Contrôles? Le Juge Des Référés et Le Maintien En Vigueur de L'état D'urgence. Note Sous Conseil d'État, 27 Janvier 2016, Juge Des Référés, Ligue Des Droits de L'homme et Autres, N 396220 (What 'Rule of Law'? What controls? The judge hearing applications for interim measures and the continued enforcement of the state of emergency. Note under Council of State, 27 Jan 2016, Judge hearing applications for interim measures. League of human rights and other rights, No. 396220). Revue Française de Droit Administratif 355

Baranger D (2016b) Quel «État de Droit»? Quels Contrôles? Le Juge Des Référés et Le Maintien En Vigueur de L'état D'urgence (What 'Rule of Law'? What controls? The judge hearing applications for interim measures and the state of emergency). Revue Française de Droit Administratif 355

\footnotetext{
${ }^{63}$ Decision no. 2016-600 QPC.

${ }^{64}$ Baranger (2016b).
} 
Cassia P (2015) Perquisitions Administratives et État D’urgence: Les Droits Fondamentaux Entre Parenthèses (Administrative searches and the state of emergency: fundamental rights in parentheses). Mediapart (16 Dec 2015). https://blogs.mediapart.fr/paul-cassia/blog/161215/ perquisitions-administratives-et-etat-d-urgence-les-droits-fondamentaux-entre-parentheses. Accessed 18 April 2017

Cassia P (2016a) Etat D’urgence: Le Pot «Pourri» de La Loi Du 21 Juillet 2016 (The state of emergency: the mixed effects of the law of 21 July 2016). Mediapart (29 July 2016). https://blogs.mediapart.fr/paul-cassia/blog/290716/etat-d-urgence-le-pot-pourri-de-la-loi-du21-juillet-2016. Accessed 18 April 2017

Cassia P (2016b) Contre l'état d'urgence. Dalloz

Kelsen H (1926) Les Rapports de Système Entre Le Droit Interne et Le Droit International. Recueil des cours de l'Académie de droit international, vol 4. Brill, Nijohff

Le Bot O (2016) État D’urgence et Compétences Juridictionnelles (State of emergency and judicial competence). Revue Française de Droit Administratif 436

Roblot-Troizier A (2016) Assignations À Résidence En État D'urgence (House arrests in a state of emergency). Note under Council of State, Section, 11 Dec 2015, M C. Domenjoud, and under Constitutional Council, 22 Dec 2015, M. Cédric. D., No. 2015-527 QPC. Revue Française de Droit Administratif 123

Roret N (2016) Etat D'urgence: Quel Rôle Pour Le Juge Pénal? (The state of emergency: what is the role of the criminal judge?). Gazette du Palais

Rosanvallon P (2015) Constitutionnaliser L'état D'urgence (Constitutionalising the state of emergency). Le Monde (12 May 2015) 